\title{
BASIC DESIGN EDUCATION AND BAUHAUS
}

\author{
Ece ESEN \\ Hacettepe University, Turkey \\ ecesen73@gmail.com \\ Gülçin Cankız ELİBOL \\ Hacettepe University, Turkey \\ https://orcid.org/0000-0002-6529-2855 \\ gcelibol@hacettepe.edu.tr \\ Duygu KOCA \\ Hacettepe University, Turkey \\ duyguk@ hacettepe.edu.tr
}

\begin{abstract}
This study investigated the Bauhaus School's recent history and its faculty members who were each deemed extraordinary, the approaches of these educators to education, the works they produced, as well as the stages of establishment of the school. In order to examine the effects of Bauhaus education in Turkey, the study covered the first three institutions of higher education which started to provide interior architecture education. The face to face interviews conducted with the instructors of the course Basic Design, which is provided as a course in the undergraduate programs of Interior Architecture and/or Interior Architecture and Environmental Design, were evaluated in line with the study's objective. ${ }^{1}$ The opinions obtained in the interviews were content-analyzed; the transcribed texts of the interviews were interpreted by coding and thematic classifications, and the existence of Bauhaus effects in the current situation in 'Basic Design' education and the state of the education in question were investigated. It was planned to create benefits in professional training and therefore improvement of the profession by the results, and contribute to the current literature on the issue by bringing a critical point of view into basic design education.
\end{abstract}

Keywords: Bauhaus, Basic Design, Interior Architecture Education

\section{TEMEL TASARIM EĞİTIMI VE BAUHAUS}

\section{$\ddot{\mathbf{O Z Z}}$}

$\mathrm{Bu}$ çalışmada, Bauhaus Okulu'nun yakın geçmişi ile her biri kendi içinde sıra dışı olarak tabir edilebilen eğitimcileri, bu eğitimcilerin eğitime olan yaklaşımları ve ürettikleri çalışmalar, okulun oluşum evreleri ile birlikte araştırılmıştır. Bauhaus eğitiminin Türkiye'deki etkilerinin incelenmesi amacıyla, iç mimarlık eğitimi vermeye başlamış ilk üç yükseköğretim kurumu araştırma kapsamına alınmıştır. Bu kurumlarda, İç Mimarlık ve/veya İç Mimarlık ve Çevre Tasarımı bölümlerinde lisans dersi olarak verilmekte olan Temel Tasarım dersi yürütücüleriyle gerçekleştirilen yüz yüze görüşmeler, çalışmanın amacı doğrultusunda ele alınmıştır . Elde edilen görüşler, içerik analizine tabi tutulmuş; çözümlemeleri yapılan görüşme metinleri kodlamalar ve tematik gruplamalar ile yorumlanarak, 'Temel Tasarım' eğitiminde Bauhaus etkisinin mevcut durumda da var olup olmadığ1 ve söz konusu eğitimde nasıl bir noktada olunduğu araştırılmıştır. Sonuçların meslek eğitimi ve dolayısıyla mesleğin gelişimi açısından fayda sağlaması, temel tasarım eğitimine konu kapsamında eleştirel bir bakış getirmesi yolu ile konuya ilişkin mevcut yazına katkı sağlaması öngörülmüştür.

\section{Anahtar Sözcükler: Bauhaus, Temel Tasarım, İç Mimarlık eğitimi}

\footnotetext{
${ }^{1}$ The data used in the study were collected in scope of the Master's thesis completed by the first author.
} 


\section{INTRODUCTION}

The Bauhaus School has established a genuine style in all fields of education with the innovative and occasionally experimental attitudes it has shown in the selection of not only educators but also students. Atalayer (1994) stated that rather than being old-school academies, traditional fine arts schools and engineering schools, Bauhaus is a special and higher combination of these; Huges (1982), on the other hand, suggested that Bauhaus is, rather than a school, actually an artistic expression and a social experiment.

Despite the effects of industrialization that started in the 19th century and made themselves felt in every part of life, the most established education reforms that were needed in the field of design and building were experienced in the Bauhaus period. The Industrial Revolution influenced the class of craftspeople which led a change in the functioning of production and brought art education into educational settings by carrying it out of the cycle of master-apprentice (Ranjan, 2005). After this point, Basic Design Education started to gain professional significance.

Basic Design education, which constitutes the back bone of Interior Architecture education, showed various changes and developments from the 17th century up to our times. Today, the course 'Basic Design' is a fundamental course taken by Interior Architecture students in their first year. Students who start to receive design education are firstly unaware that they are stepping into a different world which goes beyond the ordinary, yet they start to experience a completely different world as their awareness is raised through the experience.

Bauhaus, which was founded in the city of Weimar in Germany and provided education in the period of 1919-1933, brought a new approach towards the concept of technique, technology, art, design and production, and created a new point of view in terms of the subject of design education. Gropius, aiming to combine the mutual aspects of art and design, had the purpose of restructuring the relationship of artisans, craftspeople and architects with the industry, and as a result of this, bring art and industry under the same roof.

Bauhaus aimed to train creative architects, painters and craftspeople who have artistic capacity, and adopted the style of applied learning towards this purpose. The most significant innovation brought into Basic Design Education by Bauhaus is that it started an ordered (method, principle) and applied introduction to design course which is deliberately structured, and established an official curriculum for this course.

Being able to build the bridge between the industry, art, science and the design power of the designer and to be successful with togetherness of different disciplines, a method of working based on collaboration and an agreed-upon point of view, establishment of a 'modern style', namely an 'international style', which can be implemented in the entire world, reproduced everywhere, are the main themes that determine the establishment of Bauhaus.

The Bauhaus School has several innovations and characteristics, but what makes it valuable is the genuine artists it harbored. It would not be enough to mention only the names of these, as the phrase goes, 'heroes' of the world of design who aimed to spread the Bauhaus manifesto from the start to the finish in their schools, and even after the closure of the school in other cities and countries.

Basic Design Education (Introductory Education, Enseigment Preliminaire, Foundation Course, Vorkurs) has established the foundation of the education process in design and architecture schools. It was included in the curricula of and developed by the Base School of Design, Vkhutemas, Bauhaus, Chicago Bauhaus and the Ulm School (Hochschule für Gestaltung) (Boucharenc, 2006; Özkar, 2004; 
Meggs and Purvis, 2006). The Vorkurs spiral of education that is shown in Figure 1 shows the educational approach of the school. As clearly indicated by the known circular scheme of Gropius, it is not a process that is hierarchical and layered, but one that intertwines its components. The outer part of the schematic circle that shows the introductory stage courses which cover a 6-month process of education symbolizes Vorkurs. This section formed by Johannes Itten contains information on color, form and material. The two middle circles symbolize 3 years of education. The first group which constitutes solutions of form-based problems, provisions of technical skills and what is called 'werklehre' and may be translated as skills-teaching, consists of workshops on stone, masonry, minerals, mud, glass, colors and weaving. The second group is called 'formlehre', and as opposed to the first one, this section is concerned with the issue of creating institutional work and form.

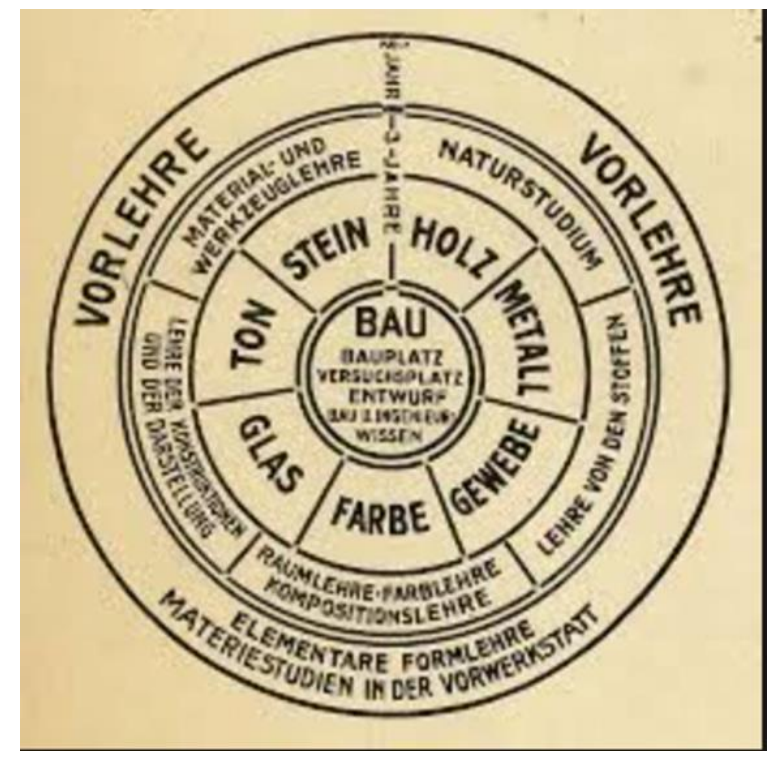

Figure 1. Vorkurs basic education spiral (Open Source Publishing, 2015).

The biggest breakthroughs in terms of Basic Design Education took place within Bauhaus and the education process developed in this school became a reference for other schools and today's process of Basic Art/Design Education.

This process is mainly in the scope of Basic Design Education, which is the first step in students' comprehension of design. This education, which is also called introductory education, is a first step for the prospective designer. In this context, skills of raising awareness, gaining visual sensibilities and comprehending how questions and solutions may be diversified, carry significant importance.

As architecture is somewhere beyond its physical dimensions; a space should activate sensual feelings through the experiences. This can be defined as a self-renewing dialect that is continuously being established between the human memory and body, or between thoughts and action (Demirel, 2015: 233). The concept of creativity, which can be defined by the main talent of the human being; the action of thinking; plays a significant role in design education. Conversion, in other words, transforming the knowledge -the experience- into new knowledge, can also be assumed as an action of creativity -the attractive force of design education (Bilir and Koçkan, 2016: 167). Design education aims to improve creativity as well as talent. Design education, actually, trains the student in terms of coping with problems, approaching them and design thinking, instead of educating the student solely in skills and techniques of basic design (Çelik, 2008: 10). 
Drafting in education is essential for students in the design disciplines for becoming more organized and for complying. However, drafting knowledge is crucial, both for comprehension of the issues and for the implementation phase (Özkan and Yıldırım, 2016: 240).

As Basic Design Education contains the combination of forms of improving mainly artistic skills in terms of content, scope, objective and planning, organizing the creative self enriching sensations both systematically and functionally and dignifying sensibility, provision of visual awareness and thinking, destruction of template-value paradigms and provision of the courage to create, these characteristics were studied, and their forms of existence were debated in continuing education.

Basic Design Education was offered as a course in Turkey for the first time in 1957 at 'Istanbul Devlet Tatbiki Güzel Sanatlar Yüksek Okulu' (Istanbul Vocational State School of Higher Education on Applied Fine Arts), known today as Marmara University (Marmara Üniversitesi, 2015). In the year 1969, it was established as a unit of 'basic art' that was required for the departments of the entire faculty at Mimar Sinan Fine Arts University, then known as the State Academy of Fine Arts (http://www.msgsu.edu.tr/faculties/guzel-sanatlar-fakultesi/temel-egitim). At the Hacettepe University Faculty of Fine Arts established in 1983 in Ankara, it was carried out in the main art fields of painting, sculpture, ceramic and glass; later, it was offered as a first-year course of 'basic art' at the department of Interior Architecture and Environmental Design established in 1987 (Hacettepe Üniversitesi, 2015). Today, Basic Art and/or Basic Design Education is carried out under different names, but with similar contents as a basic course in various design-oriented programs.

Today, Basic Art/Basic Design Education is continuing to be offered in Europe and the United States under names such as Basic Education, Basic Design, Basic Art and Introductory Education.

The objective of this study is to examine the Bauhaus School that is accepted as the starting point of the 'Basic Design' workshop course which is one of the first-year courses in Interior Architecture education in Turkey and accepted as the backbone of design education, and determine its relationships with the Basic Design Education of our time, its reflections, effects and the reasons and forms of change it experienced.

As a field study, face to face interviews were conducted with faculty members who instruct for the first Interior Architecture and/or Interior Architecture and Environmental Design departments in Turkey which structured their Basic Design based on the Bauhaus school. With this study, it was aimed to determine the current presence of the Bauhaus school in Basic Design Education and its effects.

The educational institutions covered in the study were Marmara University, Hacettepe University and Anadolu University. Marmara University was established in 1955 with the name of School of Higher Education on Applied Fine Arts, and included under the name of Marmara University in 1982. The faculty consists of 13 departments. These are; Animated Film, Industrial Product Design, Photography, Traditional Turkish Arts, Graphic Arts, Sculpture, Interior Design, Music, Painting, Ceramic and Glass, Cinema and Television, Textile Arts, and Basic Education. The Department of Interior Architecture started providing education as one of the first five departments established within the 'Vocational School of Higher Education on Applied Fine Arts'. Since the year 1985, the department started to provide graduate-level education which includes Master's and Qualification in Art degrees (Marmara Üniversitesi, 2015). Hacettepe University Faculty of Fine Arts was established in 1983. The faculty has 5 departments. These are; Painting, Sculpture, Ceramic, Graphics, and Interior Architecture and Environmental Design (Hacettepe Üniversitesi, 2015).

The Anadolu University Faculty of Art was established in 1983 as the 'Applied Fine Arts School of Higher Education'. It started operating in the academic year of 1985-1986 with the departments of Graphics and Ceramic, and it was converted to the 'Faculty of Fine Arts' in 1992. The faculty has 6 
departments. These are; Graphics, Ceramic-Glass, Cartoons (Animation), Sculpture, PaintingLithography Basic Education (service department which does not accept students). The Department of Interior Architecture and Environmental Design was established in 1991 as a part of the "Faculty of Architecture and Design' (Anadolu Üniversitesi, 2015).

\section{MATERIAL AND METHOD}

The study investigated the questions of the emergence of Basic Design Education within the Bauhaus school, how the school influenced today's education, and how has it changed so far. Since the establishment of the Bauhaus school, studies have been conducted on the education methodology it followed, course contents and structure. Within the scope of the results obtained from investigations, face to face interviews were conducted with the instructors that are carrying out the Basic Design courses offered in the departments of Interior Architecture and/or Interior Architecture and Environmental Design at Marmara University, Hacettepe University and Anadolu University, which are considered to carry the influence of Bauhaus in Turkey, and the principles and contents of their Basic Design courses were discussed. In the scope of the study, Bauhaus Basic Art/Design Education was taken as a starting point, the continuing Basic Art/Design Education of our time was investigated, and the changes and developments in experienced through time were examined. During the interviews, the instructors were asked two basic questions; however, it was possible to direct the interviews during the course of the discussion. Therefore, in these interviews that may be considered to be semistructured, audio recordings were obtained with the consent of the participants, the interviews were transcribed and recorded in text format, the data were coded and categorized, and they were then content-analyzed by classification under themes (Esen, 2015).

\section{FINDINGS}

As a result of the interviews, it was found that Basic Design Education is provided in the Department of Interior Architecture at Marmara University in the light of the Bauhaus school; however, the 'Idea of Bauhaus' has been improved and changed due to the changing century, economic conditions, educational reforms and new needs. It was seen that there is a basic education course that is a requirement for all students at the Faculty of Fine Arts, provided by the department of Basic Education, which is a department that does not produce graduates, but only provides a common-core course.

However, the Basic Design course offered by the Department of Interior Architecture differentiates from this common-core course. With the help of mainly studies on the concept of space (function is not focused on until the end of the first year) and the concept of internal space, students inquire about transitioning from two dimensions to three dimensions. The main approach of the instructors is to systematically set the students free and lead them to find their creative force. According to Ilgin (2015), the most important approach in Bauhaus is 'learning by doing'; however, restrictions brought by the Board of Higher Education (YÖK), problems in employment of technicians and shortcomings in studio conditions limit the system of 'learning by doing'; this situation is a primary issue.

The Basic Art Education course provided at the Department of Interior Architecture and Environmental Design at Anadolu University is, again, implemented in a way that aims to reveal the student's internal creative power and is structured by the instructor. According to Atalayer (2015), the essence of basic education is based on Bauhaus and it is not possible to claim the opposite. However, the conditions from which Bauhaus emerged gained a completely different dimension today due to knowledge bases, political conditions in countries, ideologies and production technology, and these changes led education to become differentiated. Today, various factors were added and various other were removed from this system. For example, Atalayer, who believes that 'architecture' is an 'art', does not believe that architecture is central in art education. However, when we consider Bauhaus education, it is known that the main approach of it is architectural. The instructor considers the student as central within the program they have structural; they use a very long-termed and experimental process as a basis for techniques such as writing, drawing, handcraft skills, usage of visual expression, 
imagination, transverse thinking, metamorphosis, self-expression. Moreover, as a technique used in Bauhaus education, the instructor focuses on the issues of 'repetition', students' personal behaviors and daily lives. The instructor aims to surpass the visual, intellectual and sensational templates that we have coded and/or learned since birth, and improve the creative force and way of thinking within us. This form of education which brings the student and the instructor into the same process of evolution is in parallel with the basic education course implemented at the Bauhaus School by Johannes Itten.

According to Ertek (2015), lack of complete implementation of Bauhaus education in the Basic Design course offered at the Department of Interior Architecture and Environmental Design at Hacettepe University is caused by lack of complete understanding of the 'Bauhaus Basic Design Education'. Regressed educational system, lack of application studios and failure to establish a polyphonic educational system are also considered as other reasons. Basic Education, which had been implemented as a 'common-core' course at the Hacettepe University Faculty of Fine Arts, is now no longer implemented due to reasons the instructor is not aware of; abolishment of this practice is considered as one of the factors that led to the disruption of communication among the departments.

The basic education provided by the Department of Interior Architecture at Hacettepe University consists of two parts as 'Basic Design' and 'Basic Art'. This was explained by the statement that Basic Art education is more 'subjective', while Basic Design education is more 'functional'. 'Gestalt principles' were used as a basis while organizing the course contents; this was supported by the 'perception principles' used in Bauhaus education. This division, which was made deliberately in the instructor's opinion, was organized with the aim of providing more intense training to the student. In both courses, based on the principle of 'learning by doing', while professional works are aimed in practice in the Basic Design studio, art education is provided in the Basic Art studio and it is aimed to form a 'professional basis' in students.

It is seen that the logic of 'interdisciplinary collaboration', another title that forms the basis of Bauhaus education, is also implemented in student projects produced at Marmara University. With this practice that is almost in its tenth year, students of the departments of Industrial Design, Textile and Graphics take on a shared project when they enter their third year. With this project, taking brand development as a starting point, Textile, Graphics and Industrial Design Students and instructors gather and conduct operations for a determined brand. With this collaboration-based project, students learn to work together, as well as concepts of art-crafts. Another approach they will implement for the first time in the academic year of 2016-2017 in their curricula in the scope of the Bologna Process which is entirely designed towards keeping Bauhaus ongoing, is that every student will take a project course from another department during their term of education.

It was found that the inter-departmental projects that had been going on up until a few years ago at the Department of Interior Architecture at Anadolu University are no longer followed.

According to Ertek (2015), Hacettepe University does not follow the approach of 'existence within the experimental and artistic setting', which is known as the essence of Bauhaus. According to the instructor, the elements that were transferred to Basic Design education from the Bauhaus school which had a real setting for art have been limited only to the topics that could be adopted into the subject of Basic Design; other fields of art such as dance and drama came to be excluded from this education.

Revisiting the education provided at Marmara University, it is seen that students and faculty members are in communication with institutions outside the university. They have initiated not only projects with universities abroad that they determine, but also projects they carry out with state offices in collaboration, based on the methods determined by the faculty. The faculty, starting with the idea that the products of students and instructors are actualized through their education and they have products that are still in serial production today, provides a basis for floating capital projects prepared by faculty members. According to the instructor, they are at a good point in terms of the idea of 
cooperation, students participate in the triennial festival they take part in every three years with their own workshops, and they find the outcomes highly positive.

\section{CONCLUSION AND RECOMMENDATIONS}

The first-year education at Interior Architecture and/or Interior Architecture and Environmental Design Departments is based on courses of Basic Art and/or Basic Design, which are generally provided as required courses. If we take the year 1919, establishment of Bauhaus, as the date of the first implementation of the course, the basic education that experienced a 96-year-long process has undeniably gone through various changes and developments. The works implemented by several artists trained by the school in fields of both art and architecture since its establishment have been reported in the literature and constituted valuable resources for the people concerned with the profession.

Although the Bauhaus School was only able to provide active education from 1919 to 1933 , its manifesto and idea of establishment have managed to pose as a strong basis for various educational institutions, instructors and courses. As a result of this study, it was observed that this approach, while only partially, is also aimed to be sustained in today's educational settings.

In the face to face interviews conducted with instructors who provided Basic Design education in the scope of the method used in the study's research model, answers were sought for the questions of whether they applied Bauhaus education in Basic Design courses, how they applied it if they did, and their reasons if they did not, and the obtained data were analyzed.

According to the analysis of the responses, it was observed that the ideas of 'interdisciplinary togetherness', 'learning by doing' and 'applied education', which constitute the essence of Bauhaus education, cannot be achieved today to a satisfactory extent due to spatial limitations, communication problems, insufficient application studios, and lack of material and trained personnel.

While the instructors were not able to implement the physical conditions of the Bauhaus school due to reasons that are not in control of, they have took its education system as an emergence/starting point and a model, and structured it by 'improvement' as suitable for the era, not by 'change'.

These educations that were organized are 'student-centered' as in Bauhaus. The objective is to help them gain the crafts skills, artistic point of view and technical skills that they may utilize through their professional lives.

Considering the results, it was concluded that Basic Design education is an important introductory process in student's lives; it is highly important that the course is well-structured. It is believed that students may utilize other fields of fine arts if the structured system is supported by current practical and theoretical methods that are already valid, and interdisciplinary, common studio courses are added to the system with an applied model of education. In this sense, it is recommended to design environments where students will be able to carry out practices and designs within shared working platforms in a system that is in parallel with their own departments, without being separated from the other fields of art.

\section{REFERENCES}

Atalayer, F. (1994a). Görsel Sanatlarda Estetik İletişim. Eskişehir: Anadolu Üniversitesi Güzel Sanatlar Fakültesi Yayınları.

Bilir, S. and Koçkan, P., (2016). "Design Ideation: Interior Architecture Education at Hacettepe University", $1^{\text {st }}$ International Symposium 'Education in Interior Architecture' in the year of German-Turkish Research Education and Innovation, Cambridge Scholars Publishing, pp 166170. 
Boucharenc, C.G. (2006). Research on Basic Design Education: An International Survey, International Journal of Technology and Design Education, 16, s. 1-30.

Çelik, G.İ. (2008). İç Mimarlık Eğitim Programlarının Karşılaştırmalı Analizine Yönelik Bir Çalışma, Yayınlanmamış Yüksek Lisans Tez, Karadeniz Teknik Üniversitesi, Fen Bilimleri Enstitüsü, İç Mimarlık Anabilim Dalı, Trabzon.

Demirel, Emre, (2015). "Innovation and Sensual Sustainability From Materials to Cities, The Cities: Security and Poverty", The 2013 meeting of the World Society for EKISTICS, Ankara, pp 231-247.

Esen, E., (2015). Bauhaus Eğitim Anlayişinin Günümüz Temel Tasarim Eğitimine Etkileri, Yayınlanmamış Yüksek Lisans Tezi, Hacettepe Üniversitesi, Güzel Sanatlar Enstitüsü, Ankara.

Faruk Atalayer ile 14 Ağustos 2015 tarihinde gerçekleştirilen kişisel iletişim. Anadolu Üniversitesi, Mimarlık ve Tasarım Fakültesi, İç Mimarlık Bölümü Öğretim Üyesi.

Hakan Ertek ile 04 Eylül 2015 tarihinde gerçekleştirilen kişisel iletişim. Hacettepe Üniversitesi, Güzel Sanatlar Fakültesi, İç Mimarlık ve Çevre Tasarımı Bölümü Öğretim Üyesi.

Huges, Q. (1982). Before the Bauhaus: The Experiment at the Liverpool School of Architecture and Applied Arts. Architectural History 25, s.102-113.

İnci Deniz Ilgın ile 01 Temmuz 2015 tarihinde gerçekleştirilen kişisel iletişim. Marmara Üniversitesi, Güzel Sanatlar Fakültesi, İç Mimarlık Bölümü Öğretim Üyesi.

Meggs, P.B. ve Purvis, A.W. (2006). History of Graphic Design. Hoboken: Wiley \& Sons Inc.

Özkan, A. and Yildırım, K., (2016). "Comparison of Conventional and Computer-aided Drafting Methods from the View of Time and Drafting Quality", Eurasian Journal of Educational Research, Issue 62, 239-254.

Özkar, M. (2004). Uncertanities of Reason; Pragmatist Plurality in Basic Design Education. Yayınlanmamış Doktora Tezi. Massachusetts: Massachusets Institute of Technology,

Ranjan, M.P. (2005) Lessons from Bauhaus, Ulm and NID: Role of Basic Design in PG Education, DETM Conference at the National Institute of Design, Ahmedabad.

Open Source Publishing, (2015), http://ospublish.constantvzw.org/blog/education/bauhaus-meets-floss Erişim tarihi: 20.06.2015

Marmara Üniversitesi, (2015), http://tem.gsf.marmara.edu.tr/genel-bilgiler Erișim Tarihi: 20.06.2015

Hacettepe Üniversitesi, (2015), http://www.gsf.hacettepe.edu.tr/?page_id=7\&lang=tr Erișim Tarihi: $\underline{20.06 .2015}$

Anadolu Üniversitesi, (2015), https://www.anadolu.edu.tr/akademik/fakulteler/262/mimarlik-vetasarim-fakultesi/genel-bilgi Erişim tarihi: 20.06.2015 